\title{
PENGARUH PUPUK ORGANIK CAIR GAMAL DAN UREA TERHADAP PERTUMBUHAN VEGETATIF BIBIT KAKAO (Theobroma cacao. L)
}

\section{EFFECT OF LIQUID ORGANIC FERTILIZER GAMAL AND UREA ON VEGETATIVE GROWTH OF COCOA SEEDS (Theobroma cacao. L)}

\author{
Mahdalena ${ }^{1}$, Tutik Nugrahini ${ }^{2,}$ Frederich Febrian Hermanda ${ }^{3}$ \\ ${ }^{1,2}$ Tenaga Pendidik Prodi Agroteknologi Faperta Universitas Widya Gama Mahakam \\ ${ }^{3}$ Mahasiswa Prodi Agroteknologi Faperta Universitas Widya Gama Mahakam \\ e-mail : mahdalena@uwgm.ac.id, tutiknugrahini@uwgm.ac.id, frederichfebryanfa@gmail.com
}

Article Submitted: 09-11-2021

Article Accepted: 27-12-2021

\begin{abstract}
Research the effect of liquid organic fertilizer gamal and urea on vegetative growth of cocoa seeds (Theobroma cacao. L). The study was conducted for 12 weeks (3 months) from July 2021 - October 2021. The research was carried out in the Agrotechnology Experimental Garden at Widya Gama Mahakam University Samarinda. Research uses The research method used a Randomized Block Design (RAK) with a $4 \times 4$ factorial experiment consisting of 3 replications. The first factor is Urea Fertilizer (U) which consists of 4 levels, namely UO (control), U1 (3 g/polybag), U2 (6 g/polybag), U3 (9 g/polybag). The second factor was Gamal Leaf POC $(G)$ which consisted of 4 levels, namely G0 (control), G1 (200 $\mathrm{ml} /$ polybag), G2 (250 ml/polybag), G3 (300 ml/polybag). The expected output is to provide information about the best dose of Urea fertilizer for the vegetative growth of cocoa seedlings for the community. Provide information about the best liquid organic fertilizer from Gamal leaves for the vegetative growth of cocoa seedlings for the community.
\end{abstract}

Keywords: Pupuk Anorganik, Pupuk Organik Cair, Theobroma

\section{PENDAHULUAN}

Kakao (Theobroma cacao .L) merupakan salah satu komoditas unggulan perkebunan sebagai penghasil devisa negara, sumber pendapatan petani, penciptaan lapangan kerja petani, mendorong pengembangan agribisnis dan agroindustri, pengembangan wilayah serta pelestarian lingkungan (Direktorat Jenderal Perkebunan, 2012).

Lada Malonan 1, merupakan jenis varietas lada yang lokal yang banyak dikembangan di Kabupaten Kutai Kartanegara, dan propinsi Kalimantan Timur pada umumnya. Lada Malonan 1 telah ditetapkan sebagai varietas unggul dengan SK dari Menteri Pertanian dengan nomor SK : 448/Kpts/KB.120/7/2015. Lada malonan 1 mempunyai beberapa keunggulan, antara lain mengadung minyak atsiri sekitar $2,35 \%$, oleoserin $11,23 \%$, dan piperin $3,82 \%$. Kandungan ini lebih tinggi jika dibandingkan dengan lada putih darii varietas Petailing 1 yang mempunyai kandungan oleoserin sebesar $10,66 \%$ dan piperin $3,03 \%$, termasuk juga lada enteng dengan kandungan minyak atsiri $2,90 \%$, piperin $3,96 \%$, dan oleoserin $12,59 \%$. Selain itu lada Malonan-1 juga toleran terhadap penyakit busuk pangkal batang dan mampu berproduksi sepanjang tahun dengan produktivitas rata-rata sekitar 2,17 ton per hektare.

Saat ini penelitian dengan perbanyakan menggunakan stek sudah banyak di lakukan pada berbagai macam media, tapi penggunaan media tanah yang berasal dari media sekam padi untuk varitas Malonan I masih jarang di lakukan. Penelitian ini di lakukan untuk mengetahui bagaimana respon dari pertumbuhan stek lada Malonan I dengan menggunakan komposisi media tanam dan jumlah ruas.

Berdasarkan uraian tersebut maka penulis tertarik untuk meneliti pengaruh komposisi media tanam dan jumlah ruas terhadap pertumbuhan stek tanaman lada (Piper nigrum. L)

\section{BAHAN DAN METODE}

Penelitian dilaksanakan selama 3 bulan, terhitung bulan Juli 2021 - Oktober 2021. Penelitian di lahan praktek Fakultas Pertanian Universitas Widya Gama Mahakam Samarinda Jln. K. H Wahid Hasyim Samarinda. Alat yang digunakan yaitu parang, cangkul, gembor, alat tulis-menulis, kamera, kalkulator, meteran mistar, jangka sorong dan timbangan. Bahan yang digunakan untuk penelitan ini adalah biji kakao, daun gamal, EM4, air, gula merah, pupuk Urea, pupuk kandang ayam dan tanah bagian atas.

Penelitian ini dilaksanakan dengan menggunakan Rancangan Acak Kelompok (RAK) dengan percobaan faktorial, dengan 2 faktor perlakuan sebagai berikut : Pupuk Urea (U) terdiri dari 4 taraf, yaitu: $\mathrm{U}_{0}$ : Tanpa Perlakuan (kontrol), $\mathrm{U}_{1}: 3 \mathrm{~g} /$ poliybag, $\mathrm{U}_{2}: 6 \mathrm{~g} /$ poliybag, $\mathrm{U}_{3}: 9$ g/poliybag

POC Daun Gamal $(\mathrm{G})$ terdiri dari 4 taraf, yaitu : $\mathrm{G}_{0}$ : Tanpa Perlakuan (kontrol), $\mathrm{G}_{1}: 200 \mathrm{ml} /$ poliybag, G2 : $250 \mathrm{ml} /$ polibag, G3 : $300 \mathrm{ml} /$ polibag 
Hasil penelitian menunjukkan bahwa Hasil penelitian menunjukan bahwa dosis pupuk Urea dan POC daun gamal yang memberikan rata-rata pertumbuhan terbaik pada interaksi U2G3 (6 g dan $300 \mathrm{ml} /$ polybag) pada parameter tinggi tanaman dan pada interaksi U3G3 (9 g dan $300 \mathrm{ml} /$ polybag) yang memberikan rata-rata pertumbuhan terbaik pada parameter jumlah daun dan diameter batang.

Secara rinci bahasan terhadap setiap variabel pengamatan adalah sebagai berikut :

Tabel 1. Rata-rata Tinggi Tanaman Umur 45 HST.

\begin{tabular}{cccccc}
\hline \multirow{2}{*}{$\begin{array}{c}\text { Pupuk Urea } \\
\text { (U) }\end{array}$} & \multicolumn{4}{c}{ POC Daun Gamal (G) } & Rata-Rata \\
\cline { 2 - 4 } & G0 & G1 & G2 & G3 & \\
\hline U0 & $19.00 \mathrm{abc}$ & $18.33 \mathrm{ab}$ & $22.00 \mathrm{abcd}$ & $24.67 \mathrm{~d}$ & 21.00 \\
U1 & $19.67 \mathrm{abc}$ & $20.17 \mathrm{abcd}$ & $21.00 \mathrm{abcd}$ & $23.17 \mathrm{bcd}$ & 21.00 \\
U2 & $22.00 \mathrm{abcd}$ & $23.67 \mathrm{~cd}$ & $18.00 \mathrm{a}$ & $25.00 \mathrm{~d}$ & 22.17 \\
U3 & $21.00 \mathrm{abcd}$ & $22.33 \mathrm{abcd}$ & $22.67 \mathrm{abcd}$ & $19.00 \mathrm{abc}$ & 21.25 \\
\hline Rata-Rata & 20.42 & 21.13 & 20.92 & 22.96 & \\
\hline
\end{tabular}

Tabel 2. Rata-rata Jumlah Daun Umur 90 HST.

\begin{tabular}{cccccc}
\hline \multirow{2}{*}{ Pupuk Urea (U) } & \multicolumn{5}{c}{ POC Daun Gamal (G) } \\
\cline { 2 - 5 } & G0 & G1 & G2 & G3 & \\
\hline U0 & $22.00 \mathrm{abc}$ & $20.33 \mathrm{ab}$ & $20.33 \mathrm{ab}$ & $19.00 \mathrm{a}$ & $20.42 \mathrm{a}$ \\
U1 & $23.33 \mathrm{abcd}$ & $21.33 \mathrm{ab}$ & $25.33 \mathrm{bcd}$ & $24.67 \mathrm{bcd}$ & $23.67 \mathrm{~b}$ \\
U2 & $22.67 \mathrm{abcd}$ & $27.00 \mathrm{~cd}$ & $23.00 \mathrm{abcd}$ & $22.67 \mathrm{abcd}$ & $23.83 \mathrm{~b}$ \\
U3 & $21.00 \mathrm{ab}$ & $24.33 \mathrm{bcd}$ & $27.33 \mathrm{~d}$ & $27.33 \mathrm{~d}$ & $25.00 \mathrm{~b}$ \\
\hline Rata-Rata & 22.25 & 23.25 & 24.00 & 23.42 & \\
\hline
\end{tabular}

Tabel 3. Rata-rata Diameter Batang 90 HST.

\begin{tabular}{cccccc}
\hline \multirow{2}{*}{$\begin{array}{c}\text { Pupuk Urea } \\
\text { (U) }\end{array}$} & G0 & G1 & G2 & G3 & Rata-Rata \\
\cline { 2 - 5 } & $9.05 \mathrm{abcd}$ & $8.34 \mathrm{a}$ & $8.67 \mathrm{abc}$ & $7.83 \mathrm{a}$ & $8.47 \mathrm{a}$ \\
\hline U0 & $9.09 \mathrm{abcd}$ & $9.85 \mathrm{bcde}$ & $9.17 \mathrm{abcd}$ & $10.56 \mathrm{def}$ & $9.67 \mathrm{~b}$ \\
$\mathrm{U} 1$ & $9.63 \mathrm{bcde}$ & $9.77 \mathrm{bcde}$ & $9.16 \mathrm{abcd}$ & $10.78 \mathrm{ef}$ & $9.83 \mathrm{~b}$ \\
U2 & $9.97 \mathrm{cde}$ & $9.29 \mathrm{abcde}$ & $11.75 \mathrm{f}$ & $11.85 \mathrm{f}$ & $10.72 \mathrm{c}$ \\
\hline U3 & 9.43 & 9.31 & 9.69 & 10.25 & \\
\hline Rata-Rata & & & &
\end{tabular}

\section{Tinggi Tanaman (cm)}

Hasil sidik ragam menunjukan bahwa interaksi pupuk Urea dan POC daun gamal tidak memberikan pengaruh nyata terhadap tinggi tanaman pada umur 30, 75 HST dan memberikan pengeruh nyata terhadap tinggi tanaman pada umur 45, 60, 90 HST. Hal ini diduga karena unsur hara $\mathrm{N}$ yang terdapat pada pupuk Urea dan POC daun gamal belum diserap dengan maksimal oleh tanaman terutama pada pertumbuhan tinggi tanaman. Tetapi pada umur 15 HST pupuk Urea dan POC daun gamal mampu memberikan pengaruh yang sangat nyata terhadap pertumbuhan tinggi tanaman. Diduga dari adanya interaksi yang terjadi pada perlakuan U2G3 mampu menyediakan unsur hara yang dibutuhkan oleh tanaman, yang mana U2 dengan dosis Urea (6 g/polybag) diyakini mampu menyediakan unsur hara $\mathrm{N}$ yang dibutuhkan oleh tanaman dalam jumlah yang cukup dan sesuai, sedangkan pada G3 dengan dosis POC daun gamal (300 $\mathrm{ml} /$ polybag) juga diyakini mampu menyediakan unsur hara $\mathrm{N}$ yang dibutuhkan oleh 
tanaman terutama pada pertumbuhan tinggi tanaman.

Apabila kebutuhan unsur hara nitrogen $(\mathrm{N})$ tercukupi, maka dapat mempercepat pertumbuhan vegetatif tanaman seperti akar batang dan daun. Sesuai dengan penjelasan Mardianto, (2014) mengatakan bahwa kandungan unsur hara terutama nitrogen mampu mendorong dan mempercepat pertumbuhan dan pertambahan tinggi tanaman. Menurut Rosmarkam dan Nasih, (2002), bahwa pupuk anorganik mengandung hara $(\mathrm{N})$ dalam jumlah cukup banyak dan sifatnya cepat tersedia bagi tanaman sedangkan pupuk organik akan melepaskan hara yang lengkap (baik makro maupun mikro) dalam jumlah yang tidak tentu dan relatif kecil selama proses mineralisasi, sehingga dengan menambah pupuk organik

\section{Jumlah Daun (helai)}

Hasil sidik ragam menunjukan bahwa interaksi pupuk Urea dan POC daun gamal tidak memberikan pengaruh nyata terhadap jumlah daun pada umur 75 HST dan memberikan pengeruh nyata terhadap jumlah daun pada umur 15 HST. Hal ini diduga karena unsur hara $\mathrm{N}$ yang terdapat pada pupuk Urea dan POC daun gamal belum diserap dengan maksimal oleh tanaman terutama pada pertumbuhan jumlah daun. Tetapi pada umur 30, 45, 60, dan 90 HST pupuk Urea dan POC daun gamal mampu memberikan pengaruh yang sangat nyata terhadap pertumbuhan jumlah daun. Diduga dari adanya interaksi yang terjadi pada perlakuan U3G3 mampu menyediakan unsur hara yang dibutuhkan oleh tanaman, yang mana U3 dengan dosis Urea (9 $\mathrm{g} /$ polybag) diyakini mampu menyediakan unsur hara $\mathrm{N}$ yang dibutuhkan oleh tanaman dalam jumlah yang cukup dan sesuai, sedangkan pada G3 dengan dosis POC daun gamal $(300 \mathrm{ml} /$ polybag) juga diyakini mampu menyediakan unsur hara $\mathrm{N}$ yang dibutuhkan oleh tanaman terutama pada pertumbuhan jumlah daun.

Menurut Lingga dan Marsono, (2010) bahwa suatu tanaman akan tumbuh subur bila elemen yang tersedia cukup dan sesuai dengan kebutuhan tanaman, penambahan unsur hara yang tepat akan menghasilkan pertumbuhan vegetatif maupun generatif yang sebanding dengan unsur hara yang diberikan. Lakitan, (2011) juga menyatakan bahwa tanaman yang tidak mendapatkan unsur hara $\mathrm{N}$ sesuai dengan kebutuhan haranya akan tumbuh kerdil dan daun yang terbentuk kecil, sebaliknya tanaman yang mendapatkan unsur hara $\mathrm{N}$ yang sesuai dengan kebutuhan haranya akan tumbuh tinggi dan daun yang terbentuk lebar dan banyak.

\section{Diameter Batang (mm)}

Hasil sidik ragam menunjukan bahwa interaksi pupuk Urea dan POC daun gamal memberikan pengaruh nyata terhadap diameter batang pada umur 30 HST. Hal ini diduga karena unsur hara $\mathrm{N}$ yang terdapat pada pupuk Urea dan POC daun gamal belum diserap dengan maksimal oleh tanaman terutama pada pertumbuhan diameter batang. Tetapi pada umur 15, 45, 60, 75 dan 90 HST pupuk Urea dan POC daun gamal mampu memberikan pengaruh yang sangat nyata terhadap pertumbuhan diameter batang.

Diduga dari adanya interaksi yang terjadi pada perlakuan U3G3 mampu menyediakan unsur hara yang dibutuhkan oleh tanaman, yang mana U3 dengan dosis Urea (9 g/polybag) diyakini mampu menyediakan unsur hara $\mathrm{N}$ yang dibutuhkan oleh tanaman dalam jumlah yang cukup dan sesuai, sedangkan pada G3 dengan dosis POC daun gamal (300 $\mathrm{ml} /$ polybag) juga diyakini mampu menyediakan unsur hara $\mathrm{N}$ yang dibutuhkan oleh tanaman terutama pada pertumbuhan diameter batang.

Menurut Ibrahim dan kasno, (2008) menyatakan bahwa unsur hara makro yang paling banyak dibutuhkan tanaman adalah unsur hara $\mathrm{N}$ karena sangat berperan dalam fase vegetatif tanaman untuk pembentukan senyawa- senyawa protein dalam tanaman. Menurut Ardina dkk, (2016) bahwa batang merupakan daerah akumulasi tanaman khususnya pada tanaman yang lebih muda sehingga dengan adanya unsur hara $\mathrm{N}$ dapat mendorong pertumbuhan vegetatif tanaman, diantaranya pembentukan klorofil pada daun yang akan memacu laju fotosintesis, semakin laju fotosintesis maka fitosintat yang dihasilkan akan memberikan ukuran pertambahan diameter batang yang lebih besar.

\section{KESIMPULAN}

Berdasarkan hasil analisis dan pembahasan dapat disimpulkan beberapa hal, yaitu sebagai berikut :

1. Pemberian pupuk Urea dengan dosis yang berbeda tidak memberikan pengaruh nyata terhadap pertumbuhan tinggi tanaman selama penelitian dengan rata-rata tertinggi yaitu U2 (6 g/polybag), sedangkan untuk jumlah daun dan diameter batang berpengaruh sangat nyata dengan perlakuan terbaik yaitu U3 (9 $\mathrm{g} /$ polybag).

2. Pemberian POC Daun Gamal dengan dosis yang berbeda memberikan pengaruh yang sangat nyata terhadap pertumbuhan tinggi tanaman dan diameter batang selama penelitian dengan perlakuan terbaik yaitu G3 (300 $\mathrm{ml} /$ polybag) sedangkan untuk jumlah daun tidak berpengaruh nyata dengan rata-rata tertinggi yaitu $\mathrm{G} 3(300 \mathrm{ml} /$ polybag)

3. Interaksi kedua perlakuan pupuk Urea dan POC Daun Gamal memberikan pengaruh yang nyata terhadap pertumbuhan tinggi tanaman dengan perlakuan terbaik yaitu U2G3 (6 g dan 300 $\mathrm{ml} /$ polybag), sedangkan untuk jumlah daun dan diameter batang berpengaruh sangat nyata dengan perlakuan terbaik yaitu U3G3 (9 g dan 


\section{$300 \mathrm{ml} /$ polybag).}

\section{UCAPAN TERIMA KASIH}

Terima kasih dan apresiasi yang sebesarbesarnya kepada : Ketua Pengurus Yayasan Pembina Pendidikan Mahakam, Rektor Universitas Widya Gama Mahakam Samarinda, Kepala Lembaga Penelitian Dan Pengabdian Masyarakat UWGM Samarinda, Dekan Fakultas Pertanian UWGM Samarinda serta semua pihak yang telah membantu yang tidak dapat disebutkan satu persatu, atas bantuan dana internal Universitas Widya Gama Mahakam Samarinda pada skim hibah penelitian Tahun Akademik Ganjil 2021/2022.

\section{DAFTAR PUSTAKA}

Badan Penelitian dan Pengembangan Pertanian. (2008). Panduan Praktis Budidaya Kakao (Theobroma cacaoL). Badan Penelitian dan Pengembangan Pertanian [Internet]. [diunduh 2021 Maret 03]. Tersedia pada:https://scholar. Google.co.id/scholar?hl=id\&as_sdt=0\%2C5\& $\mathrm{q}=$ respon+pertumbuhan+bibit+kakao\&oq=\#d $=\mathrm{gs} \_q \mathrm{abs} \& \mathrm{u}=\% 23 \mathrm{p} \% 3 \mathrm{DCVuUe} \_\mathrm{ctR} 4 \mathrm{IJ}$

Direktorat Jenderal Perkebunan. (2012). Volume dan Nilai Ekspor, Impor Indonesia. [Internet]. [diunduh 2021 Maret 03]. Tersedia pada:https://talenta.usu.ac.id/joa/article/down $\underline{\text { load} / 2601 / 1982 / 8326}$

Ibrahim, A. S. dan A. Kasno. (2008). Interaksi Pemberian Kapur dan Pemupukan Urea Terhadap Kadar N Tanah dan Serapan N Tanaman Jagung (Zea mays). Balai Penelitian Tanaman Pangan, Semarang.

Lingga, P. dan Marsono. (2003). Petunjuk Penggunaan Pupuk. Penebar Swadaya. Jakarta. 15 hal.

Lingga, P. dan Marsono. (2010). Petunjuk Penggunaan Pupuk. Penebar Swadaya, Jakarta.

Lakitan, B. (2011). Dasar-Dasar Fisiologi Tumbuhan. Rajagrafindo Persada. Jakarta. 206 Hal.

Mardianto, R. (2014). Pertumbuhan dan Hasil Cabai (Capsicum annum L.) Dengan Pemberian Pupuk Organik Cair Daun Tithonia dan
Gamal. Malang. Universitas Muhammadiyah. 7 (2) : 61-68.

Masluki. (2015). Penggunaan Pupuk Cair Daun Gamal (Gliricidia sepium) Untuk Pertumbuhan Bibit Tanaman Kakao (Theobroma kakao L.) Jurnal Pertanian Berkelanjutan [Internet]. [diunduh 2021 Maret 15];4(1) 1-11. Tersedia Pada:https://scholar.google.co.id/scholar?hl=id\&as_sdt=0\%2C5\& $\mathrm{q}=$ dosis+poc+daun+gamal+terhadap+bibit+ka kao+ $1+$ bulan\&btnG=\#d=gs_qabs\&u=\%23p\% 3DU5jPrHjqWUkJ

Masluki. (2015). Respon Berbagai Dosis Pupuk Nitrogen Terhadap Pertumbuhan Bibit Kakao. Jurnal Perbal [Internet]. [diunduh 2021 Maret 15]; 3(3) 1-11. Tersedia Pada:https://journal.uncp.ac.id/index.php/pe rbal/article/view/722/615

Nusantara, S. (2009). Keunggulan Gamal sebagai Pakan Ternak. BPTU Sembawa. Ditjen Peternakan dan Keswan Jl. Raya Palembang Pangkalan balai Km. 29 Sembawa

Pusat Penelitian Kopi dan Kakao Indonesia. (2010). Buku Pintar Budidaya Kakao. Jakarta. Penerbit Agromedia Pustaka.

Prihmantoro, H. Dan Y. H. Andriani. (2017). Petunjuk Praktis Memupuk Tanaman. Bogor. Penebar Swadaya Grup.

Rosmarkam, A. dan Nasih Widya Y. (2002). Ilmu Kesuburan Tanah, Kanisius, Yogyakarta.

R. Purba., E. Sutrisno, dan S. Sumiyati. (2013). Pengaruh Penambahan Limbah Udang Pada Pupuk Cair dari Fermentasi Urin Sapi Terhadap Kualitas Unsur Hara Makro. Jurnal Tekhnik Lingkungan.

Ramadhani, R.H., Roviq, M., dan Maghfoer, M.D. (2016). Pengaruh Sumber Pupuk Nitrogen dan Waktu Pemberian Urea Pada Pertumbuhan dan Hasil Tanaman Jagung manis (Zea Mays Sturt. Van. Saccaharata). Jurnal Produksi Tanaman [Internet]. 4(1)1-2. Tersedia Pada:https://jurnal.uisu.ac.id/index.php/agrila nd/article/download/2550/1693 